\title{
The Unspoken Truth: Evaluating Attitudes Toward Immigration in Missouri
}

\author{
J.S. Onésimo Sandoval (Corresponding author) \\ Department of Sociology \& Anthropology, Saint Louis University \\ Saint Louis, MO 63108, United States
}

Tel: 1-314-977-2613 E-mail: jsandov3@slu.edu

\begin{abstract}
Lisa Dorner
Educational Leadership \& Policy Analysis, University of Missouri-Columbia Columbia, MO, 65211, United States
\end{abstract}

Tel: $1-573-882-7938$

Jodi Devonshire

Regional Center for Education and Work, University of Missouri-St. Louis

St. Louis, MO 63121, United States

Tel: 1 - 314-516-6437

Received: March 26, 2014 Accepted: May 3, 2010 Published: May 25, 2014

doi:10.5296/ijssr.v2i2.5365 URL: http://dx.doi.org/10.5296/ijssr.v2i2.5365

\begin{abstract}
Immigration remains a politically contentious issue around the United States. In this study, we explore the attitudes of Missouri residents toward immigrants residing in the state. While the immigrant population has increased $172 \%$ since 1980 , foreign-born residents remain relatively few in number, comprising a mere $4 \%$ of the state's population in 2010 . Small population size notwithstanding, state legislators have submitted numerous bills limiting the rights of the immigrant population over the past several years. Nonetheless, our findings, in this research paper, suggest that most Missourians actually hold positive views of the contributions that immigrants make in the state. Drawing on data collected in a representative
\end{abstract}


telephone survey of Missouri residents over the age of $18(n=800)$, we found that most Missouri residents perceived immigrants as sharing their values on important issues.

Keywords: immigration, public opinion, Missouri

\section{Introduction}

Immigration has long been a contested issue in the United States (Higham, 1955). While politicians remind audiences that the United States is a nation of immigrants, foreign-born residents are often portrayed in public media as a threat to social cohesion and a drain on public resources. This tendency of looking "to earlier waves of migrants through rose colored glasses while exhibiting concern about the absorption of current and future immigrants" (Martin, 2003, p. 132) is widely reflected in attitudinal ambivalence about contemporary immigration in public polling (Harwood, 1986; C. Suárez-Orozco \& M. Suárez-Orozco, 2001). The tension between these two perspectives, combined with high levels of international migration to the United States in the post-1965 era, create a need for theoretically and empirically rigorous studies of public attitudes toward immigration. This paper extends the growing literature on attitudes toward immigration through an analysis of public opinion in a non-traditional immigration destination state (Hood IIII \& Morris, 1997). Drawing on data from a representative survey of residents in Missouri, the paper provides a detailed analysis of public attitudes toward immigration-related issues. We will argue that while immigration remains low on the list of political priorities from many Missourians, attitudinal ambivalence among respondents creates some instances of support for immigrants and their children.

Public opinion regarding immigration, at the state level, has become increasingly important over the past decade. While the federal government holds plenary power over immigration and citizenship, there has been a widespread move toward state and local interventions in the immigration arena. State governments have passed laws and resolutions addressing a host of issues, including everything from driver's licenses to 'English-only' mandates and education to law enforcement-related bills (NCLS, 2013). Some scholars have argued that this shift represents the devolution of power from the federal government to the states (Ellis 2006), while other have noted that many sub-national policy efforts were inspired by grassroots activism emerging in response to place-based contexts (Walker \& Leitner, 2011). What is clear in both accounts is the increasingly important role that state policies play in terms of immigrant incorporation and membership (Ellis \& Almgren, 2009).

Over the past decade, state laws governing immigration have gained widespread media attention, particularly Arizona's legislation, which was partially overturned in federal court. However, the connection between public attitudes toward immigration and legislation is not always clear. Furthermore, the specific historical, social, and geographic contexts of individual states may significantly influence attitudes toward immigration (Portes \& Rumbaut, 2006). Although Missouri is home to two major metropolitan areas (St. Louis and Kansas City) and numerous smaller municipalities with growing immigrant populations, it 


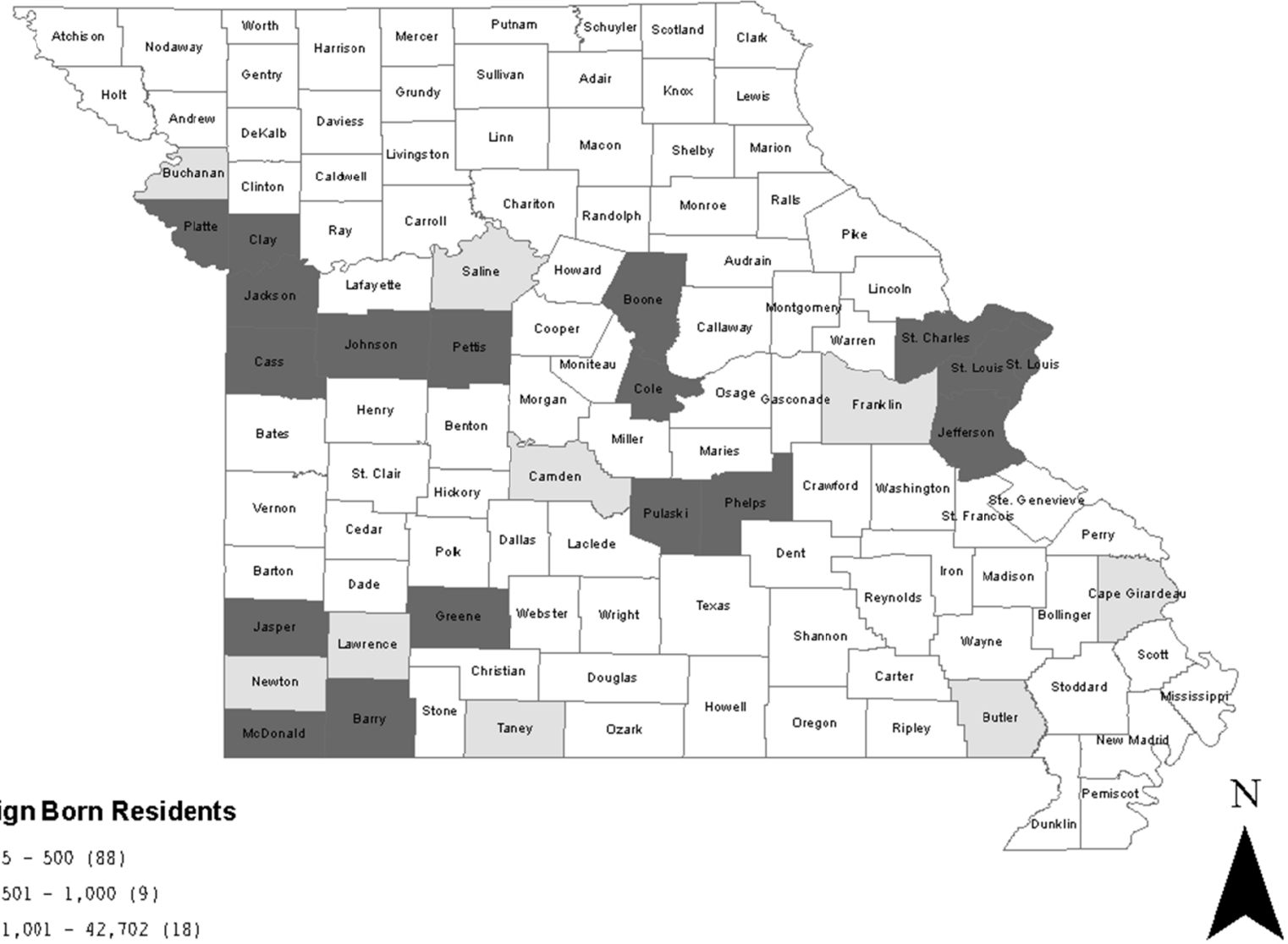

Figure 1. Foreign born residents by county (2000)

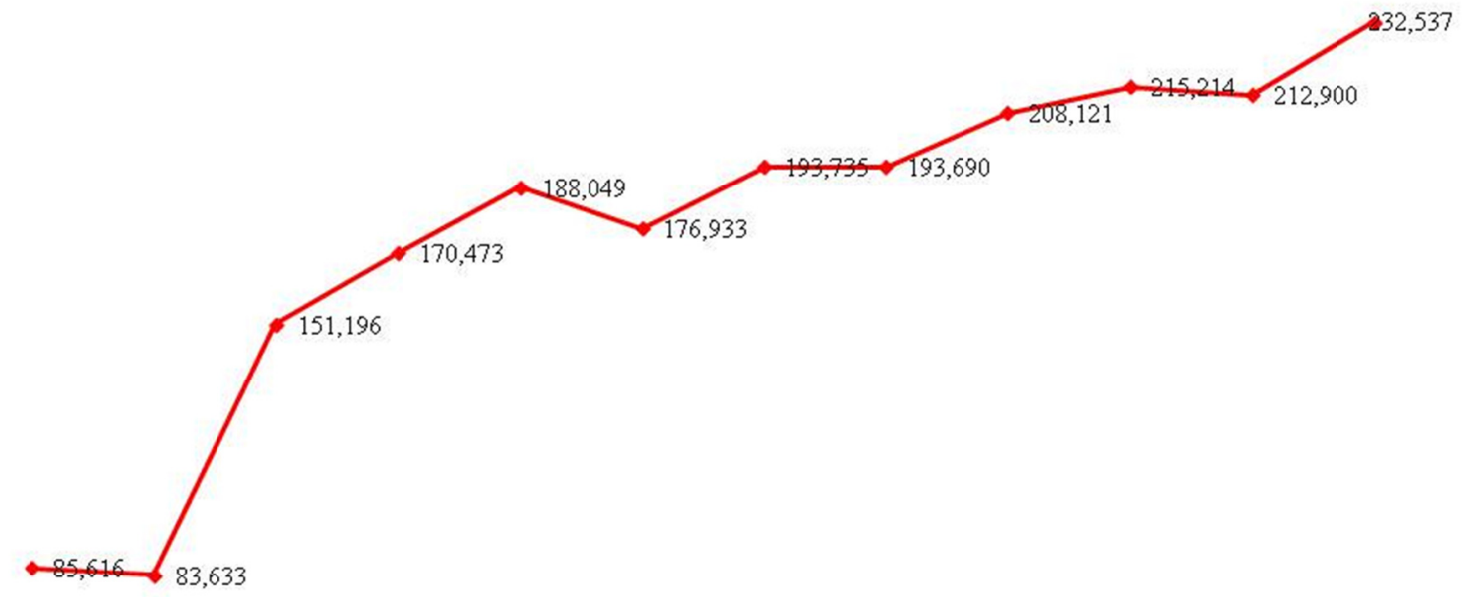

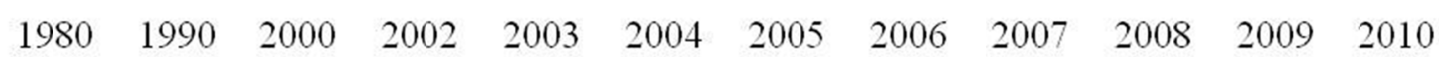

Figure 2. Number of immigrants in Missouri 
does not have the historical tradition of immigration associated with states along the U.S.-Mexico Border, New York, or even neighboring Illinois. While the immigrant population has increased $172 \%$ since 1980 and every county had an immigrant in 2000, foreign-born residents remained relatively few in number, comprising a mere $4 \%$ of the state's population in the 2010 American Community Survey Estimates (See Figures 1 and 2). Meanwhile, despite the limited number of foreign-born residents in Missouri, state legislators have repeatedly submitted and even passed legislation seeking to restrict the immigrant presence in Missouri. Our aim in this paper is twofold: (1) to extend our knowledge of determinates of attitudes toward immigration in a non-traditional immigrant gateway state, and (2) to identify potential disjunctures between state-level policies and public attitudes towards immigration in Missouri.

The paper begins with an overview of the literature on determinants of attitudes toward immigration. We then provide a detailed account of our research methods, including a discussion of the development of this study as a Participant Action Research (PAR) project. The following section outlines our key findings, including a discussion of several important areas of support for immigrant rights in Missouri. The paper concludes with a short discussion of the implications of our findings for public policy in Missouri.

\section{Theoretical Framework}

Growing immigrant populations in the United States ensure that immigration, including both documented and undocumented, will remain a contentious political issue in the coming decades. Because legal immigration levels are controlled by the federal government, public attitudes toward immigration may, at times, have significant implications for immigration policy. National public opinion polls, for example, show that while there has never been a majority of U.S. voters in favor of greater levels of immigration, during periods of economic stress there have been times when a majority of Americans wanted to reduce immigration levels (Simon and Lynch 1999). Over the past two decades, numerous studies have examined the factors that shape such attitudes towards immigration. While the recent literature on public attitudes towards immigration is disparate in nature and has evolved across a variety of disciplines, in this section we outline some of the key themes from recent studies as a point of departure for our own efforts to model attitudes towards immigration in Missouri.

While noting the difficulty of providing a unified theory of public attitudes towards immigration, Chandler and Tsai (2001) offer a useful typology for organizing the most prevalent factors in the literature evaluating attitudes toward immigration. Their schema includes ascribed background characteristics, self-interest, ideologies, and group comparison variables. The first category, ascribed background characteristics, focuses on demographic variables such as age, sex, and race/ethnicity. The second category, self-interest, is based on the "common assumption that individuals pursue self-interest in forming their view...such as source and amount of income, perceived effects of policies upon economic conditions and/or personal safety" (p. 179). The third category, ideologies, is generally understood to represent political orientation (e.g., conservative, liberal, or party affiliation). Group comparisons comprise the fourth category and refer to collective identities such as 
nationality, or membership in a particular social network that may influence an individual's perceived cultural threat. Education is also included in the group comparison category as a key factor in shaping group comparisons. Finally, for the purposes of this research, we add geography as an additional variable group. Geography has been used as a referent in previous studies, but this has generally been an under-valued factor in assessing the formation of attitudes towards immigration. This typology offers a useful roadmap for organizing the recent literature on public opinion around immigration, but it is also important to note the diversity of the literature and to recognize that some theories and approaches do not fall neatly within the boundaries of this structure.

\subsection{Ascribed Background Theory}

Ascribed Background Characteristics including sex, age, and race/ethnicity are widely incorporated into studies seeking to evaluate the formation of attitudes toward immigration among the general public (Espenshade \& Calhoun, 1993; Espenshade \& Hempstead, 1996; Hood III \& Morris, 1997). However, the predictive power of individual characteristics varies across scope of the recent literature. Age, sex, and race/ethnicity appear to have relatively weak influence on larger patterns of attitude formation, though overall the findings are mixed. Researchers have hypothesized that individuals whose age, sex, or race/ethnicity puts them in tenuous positions in the work force or in terms of personal economics may be less likely to have positive attitudes toward immigration. Wilkes et al. (2008) note for example, that "in the case of women [their lack of support for immigration] has been linked to their more tenuous labor market positions, though most studies...provide little in the way of explanation for the effect of gender" (p. 306). Others find that there is little indication in the extant literature that sex plays a significant role in shaping attitudes toward immigration (Chandler \& Tsai, 2001). Likewise, the connection between age and attitudes toward immigration is mixed. Espenshade and Hempstead's (1996) analysis of national scale data found no correlation between age and attitudes. However, Chandler and Tsai (2001) reported in their analysis of the National General Social Survey (GSS) data that "older respondents [are] more likely to want to decrease number of legal admissions" (p. 181). Finally, race and ethnicity are also associated with shaping attitudes, with relative labor market position again playing an important role. One hypothesis suggests that because African Americans are likely to be negatively affected by labor force competition with new immigrants, that they are more likely to hold more negative attitudes toward immigrants. In an analysis of a series of public opinion polls, Diamond (1998) offers the more complex finding that African Americans, in comparison to whites, are less likely to support restrictive immigration policies. However, in questions on the economic costs associated with immigration, African Americans are more likely to be restrictionist in their views of immigration. Latinos generally hold positive attitudes toward immigrants, primarily based on a feeling of solidarity with immigrants (Binder et al., 1997; Lopez \& Pantoja, 2004; Pantoja, 2006).

\subsection{Self-Interest and Ideology Theory}

Self-interest represents a second area that researchers have examined in seeking to understand attitudes towards immigration. Economic self-interest is most closely associated with the 
labor market hypothesis, which in turn is based on an individual's economic position in society and their relative sense of economic security. The labor market hypothesis follows rational choice theory by suggesting that an individual's economic stability and income will significantly influence their attitudes toward immigrants. Thus, "job holders at the bottom of the socioeconomic ladder are assumed to be most susceptible to these forms of labor market competition, because low skill and low wage native workers have occupational characteristics similar to those of today's new immigrants" (Espenshade \& Hempstead, 1996). Economists Scheve and Slaughter (2001) examine the labor market competition hypothesis and find that less-skilled workers are "significantly more likely to prefer limiting immigrant inflows into the United States" (p. 135). However, Pantoja (2006) notes that "although researchers have long noted the primacy of economic conditions in underlying attitudes toward immigration, more recent studies have found a weak connection between personal and national economic evaluations and restrictive sentiments" (p. 519). Thus, while researchers have long associated labor force competition and restrictionist attitudes toward immigration, recent findings suggests that other factors including group dynamics and deeply held attitudes may have a stronger influence on attitude formation (Hainmueller \& Hiscox, 2007).

The influence of ideologies on attitudes toward immigration is often difficult to evaluate, but in this study we use straight-forward questions about political affiliation. In general terms, conservatives or republican-leaning individuals are more likely to favor restricting immigration flows, while liberal or democrat-leaning voters tend to have more favorable attitudes towards higher levels of immigration (Espenshade \& Hempstead, 1996; Citrin et al., 1997; Sheve \& Slaughter, 2001).

\subsection{Group Comparison Theory}

Group Comparisons provide important insights into the ways that attitudes toward immigrants are formed. Theories of group contact and group threat highlight interactions between ethnic groups that may significantly influence overall attitudes toward immigration. Group contact theory (Blumer, 1958; Quillian, 1995) suggests that prejudice against immigrants is based on interactions between groups, and that changes in the composition and size of 'out groups' (i.e., immigrants) may lead to higher levels of prejudice in society. Quillian (1995) also found support for two group threat hypotheses: (1) "is influenced both by the economic situation faced by the dominant group and by the size of the subordinate group relative to the dominant group" and (2) "individual-level prejudice emerges when the perceived threat posed by the subordinate group is greater" (p. 592). Dixon (2006) argues that theories of group contact and group threat are not necessarily incompatible because these theoretical frameworks offer a valid analysis of race relations of whites toward Hispanics and Asians.

The influence of inter-group comparisons may also be seen in other contexts, including through shared immigrant status, union membership, and educational attainment. Recent immigrant status, for example, is often a strong predictor of positive attitudes toward immigration (Haubert \& Fussell, 2006). Wilkes et al. (2008), in a study of Canadian immigration, found that "people with a non-majority first language hold much more positive 
attitudes about immigration than do members of the majority group" (p. 324). Thus, having ties to the 'recent immigrant out-group' increases the likelihood of holding pro-immigrant attitudes.

Likewise, union membership may influence attitudes towards immigrants, despite the fact it has received minimal attention in the literature. Labor unions have historically been perceived as supporting limitations on immigration in a state-centric effort to ensure higher wages, but over the past several decades, some unions in the United States have chosen not to focus on fighting liberal immigration policies and have chosen to focus instead on organizing immigrant workers (Haus, 1995). Such efforts to organize immigrant workers suggest that union membership may also play a role in shaping union members' attitudes toward immigration.

Education is another key group comparison with strong implications for attitudinal formation around immigration (Scheve \& Slaughter, 2001). The extant research suggests a consistently strong relationship between education level and attitudes toward immigration (Espenshade \& Calhoun, 1993; Citrin et al., 1997). In general terms, individuals with higher levels of education tend to display lower levels of prejudice and more positive attitudes toward immigrants. Numerous studies have utilized education level as a proxy for measuring labor market theories (i.e., individuals who have fewer years of education are more likely to be doing jobs that bring them into competition with recent immigrants in the work force). Hainmueller and Hiscox (2007), however, challenge the connection between education and economic self-interest, finding that "anti-immigrant sentiments appear to be far more powerfully associated with cultural values that have more to do with conceptions of national identity than they do with concerns about personal, economic circumstances" (p. 437). Hubert and Fussell (2006), in contrast, suggest that education plus a cosmopolitan world view is a strong predictor of pro-immigrant attitudes. They find that individuals who have completed a college degree and have lived abroad are more likely to have a cosmopolitan perspective, which in turn is associated with a positive attitude toward immigration.

In summary, attitudes toward immigration are shaped by factors ranging from individual demographic characteristics to the composition of personal networks and the quality and quantity of interactions with immigrants on a daily basis. The existing literature offers a rich base for exploring factors that shape attitudes toward immigration for Missourians. Our research in this paper contributes to the growing and diverse literature on public attitudes in an effort to better understand public attitudes toward immigration in a non-traditional immigration gateway state.

\section{Research Question and Methodology}

Missouri legislators, despite the small size of the immigrant population in the state, filed numerous bills between 2006 and the time that this research was conducted in 2010. In response to this anti-immigration effort, Missouri Immigrant and Refugee Advocates (MIRA) and the Service Employees Union International (SEIU) of Missouri approached Saint Louis University to evaluate the potential for a "Welcoming Missouri" initiative for immigrants. After working together for a year on the "Welcoming Missouri" initiative we developed a 
research design that included qualitative and quantitative methods. The quantitative part of the project was designed to provide scientific evidence to more accurately measure attitudes toward immigration in Missouri. The name of the survey was the MIRA Public Opinion Survey (henceforth MIRAPOS). The research design for MIRAPOS would be based on a cross-sectional survey design. The research team agreed that a three call design would be appropriate for Missouri, and only individuals 18 years old or older would be eligible to complete the survey. Given the immediate nature of the survey results and budget, the research team concluded that our sample size should be about 800 individuals. The surveys were conducted during the month of October 2010. The final sample was 800 individuals. This sample produced a margin of error $+-3.5 \%$. The analysis was performed in a statistical package called SAS.

The research was driven by four questions: (1) Do Missourians have a positive view of immigrants? (2) How does the view of immigrants relate to individuals who have familial ties to immigrants or unions? (3) Is the view of immigrants related to social justice? and (4) Is the view of immigrants related to the anti-immigrant bill in Arizona? MIRA planned to use the results from the four questions to build a marketing campaign to educate the state about the positive role that immigrants play in Missouri. The general feeling of the research team was that the majority of individuals would report negative attitudes toward immigrants. Our dependent was derived from the question, Do you think immigrants have a positive or negative effect on Missouri? Given that the options for a response was yes and no, the best statistical method to use to answer these questions was logistic regression, which is defined in Equation 1:

$$
\hat{p}=\frac{e^{\beta_{0}+\beta_{1} X_{1}}}{1+e^{\beta_{0}+\beta_{1} X_{1}}}
$$

Using Equation 1, we computed four logistic regression models. Model 1 was a baseline model that included demographic variables. Model 2 estimated the familial and union ties to immigrants. Model 3 estimated three scaled policy variables created using factor analysis. Model 4 estimated all the variables in Model 1, 2, and 3.

To reduce the number of independent variables in the model and reduce multicollinearity, we used a factor analysis. Three factors were identified as significant: (1) American Values; (2) Social Justice; and (3) Arizona Principles. The variables that highly contributed to the American Values factor were: have good family values was ranked first (mean=3.13) followed by wants to become U.S. citizens (mean=2.94), works at jobs Americans don't want to do (mean=2.86), loyal to America (mean=2.67), wants to learn English (mean=2.57), and pays taxes (mean=2.30). The variables that highly contributed to the Social Justice factor were: deny social services for immigrant children (mean=2.56), provide access to health care (mean=3.26), provide access to public education (mean=3.31), and provide in state tuition (mean=3.21). The variables that highly contributed to the Arizona Principle factor: local and state law enforcement officers should be required to determine whether a person is a U.S. citizen or legal resident when they issue a citation for a violation of municipal building code such as grass being too high or unlicensed vehicles present in the driveway (mean=3.43) and 
local and state law enforcement officers should be required to determine whether a person is a U.S. citizen or legal resident when they question the person as witness, not a suspect, to the commission of a crime (mean=3.47) (See Table 1).

Table 1. Variables that contributed to Factors 1, 2, and 3

\begin{tabular}{|c|c|c|c|c|c|c|c|c|c|}
\hline Variable & Label & Scale & Mean & $\begin{array}{l}\text { Std } \\
\text { Dev }\end{array}$ & Minimum & Maximum & $\begin{array}{l}\text { Factor One } \\
\text { Loading } \\
\text { Score }\end{array}$ & $\begin{array}{l}\text { Factor } \\
\text { Two } \\
\text { Loading } \\
\text { Score }\end{array}$ & $\begin{array}{l}\text { Factor } \\
\text { Three } \\
\text { Loading } \\
\text { Score }\end{array}$ \\
\hline Q8 & Have Good Family Values & $\begin{array}{l}4=\text { Very Well; } \\
1=\text { Not At All }\end{array}$ & 3.13 & 0.77 & 1 & 4 & 0.64 & & \\
\hline Q9 & $\begin{array}{l}\text { Works at Jobs Americans Don't } \\
\text { Want To Do }\end{array}$ & $\begin{array}{l}4=\text { Very Well; } \\
1=\text { Not At All }\end{array}$ & 2.86 & 0.97 & 1 & 4 & 0.46 & & \\
\hline Q10 & Pay Taxes & $\begin{array}{l}4=\text { Very Well; } \\
1=\text { Not At All }\end{array}$ & 2.30 & 1.00 & 1 & 4 & 0.70 & & \\
\hline Q11 & Loyal to America & $\begin{aligned} 4 & =\text { Very Well; } \\
1 & =\text { Not At All }\end{aligned}$ & 2.67 & 0.96 & 1 & 4 & 0.74 & & \\
\hline Q12 & Wants to Become U.S. Citizens & $\begin{aligned} 4 & =\text { Very Well; } \\
1 & =\text { Not At All }\end{aligned}$ & 2.94 & 0.95 & 1 & 4 & 0.77 & & \\
\hline Q13 & Wants to Learn English & $\begin{aligned} 4 & =\text { Very Well; } \\
1 & =\text { Not At All }\end{aligned}$ & 2.57 & 1.04 & 1 & 4 & 0.75 & & \\
\hline Q35 & $\begin{array}{l}\text { Denying social services to } \\
\text { children of immigrants is all } \\
\text { right }\end{array}$ & $\begin{array}{l}\text { 5=Strongly } \\
\text { Agree } 1 \\
=\text { Strongly } \\
\text { Disagree* }\end{array}$ & 2.56 & 1.27 & 1 & 5 & & 0.48 & \\
\hline Q36 & $\begin{array}{l}\text { Children of undocumented } \\
\text { immigrants deserve to have } \\
\text { access to health care }\end{array}$ & $\begin{array}{l}\text { 5=Strongly } \\
\text { Agree; } 1 \\
\text { =Strongly } \\
\text { Disagree }\end{array}$ & 3.26 & 1.28 & 1 & 5 & & 0.68 & \\
\hline Q37 & $\begin{array}{l}\text { Children of undocumented } \\
\text { immigrants deserve to have } \\
\text { access to public education }\end{array}$ & $\begin{array}{c}5=\text { Strongly } \\
\text { Agree; } 1 \\
=\text { Strongly } \\
\text { Disagree }\end{array}$ & 3.31 & 1.31 & 1 & 5 & & 0.69 & \\
\hline Q38 & $\begin{array}{l}\text { Undocumented immigrant } \\
\text { students who have been living } \\
\text { in Missouri for more many } \\
\text { years have a right to be charged } \\
\text { in-state tuition when they attend } \\
\text { state universities }\end{array}$ & $\begin{array}{c}5=\text { Strongly } \\
\text { Agree; } 1 \\
=\text { Strongly } \\
\text { Disagree }\end{array}$ & 3.21 & 1.35 & 1 & 5 & & 0.74 & \\
\hline Q44 & $\begin{array}{l}\text { Local and state law } \\
\text { enforcement officers should be } \\
\text { required to determine whether a } \\
\text { person is a U.S. citizen or legal } \\
\text { resident when they issue a } \\
\text { citation for a violation of } \\
\text { municipal building code such as } \\
\text { grass being too high or } \\
\text { unlicensed vehicles present in } \\
\text { the driveway }\end{array}$ & $\begin{array}{c}5=\text { Strongly } \\
\text { Agree } 1 \\
=\text { Strongly } \\
\text { Disagree* }\end{array}$ & 3.43 & 1.38 & 1 & 5 & & & 0.83 \\
\hline Q45 & $\begin{array}{l}\text { Local and state law } \\
\text { enforcement officers should be } \\
\text { required to determine whether a } \\
\text { person is a U.S. citizen or legal } \\
\text { resident when they question the } \\
\text { person as witness, not a suspect, } \\
\text { to the commission of a crime }\end{array}$ & $\begin{array}{l}5=\text { Strongly } \\
\text { Agree } 1 \\
=\text { Strongly } \\
\text { Disagree* }\end{array}$ & 3.47 & 1.35 & 1 & 5 & & & 0.83 \\
\hline & Eigenvalue & & & & & & 4.07 & 1.40 & 1.21 \\
\hline
\end{tabular}




\section{Macrothink}

\section{Findings}

Eight-hundred Missourians over 18 participated in MIRAPOS. The average age was 56 years. Forty-eight percent of the respondents were male and 52\% were female. About eight out of ten respondents were white $(82 \%), 7 \%$ were black, and $11 \%$ were of another race. Seven percent of the respondents did not complete high school. This compares to $40 \%$ that had a college degree $(26 \%)$ or post college education (14\%). Half of the respondents classified themselves as independent or other (50\%), 27\% classified themselves as Democrat, and 23\% classified themselves as Republican. About four out of ten (38\%) of the respondents were from the Saint Louis metropolitan statistical area and $18 \%$ of the respondents were from the Kansas City metropolitan statistical area. Finally, 44\% of the respondents reported that they were an immigrant or had a family member that was an immigrant and $41 \%$ reported that they were a member of a union or had a family member that was a member of a union (See Table 2).

Table 2. Definition of key variables used in the logistic regression models

\begin{tabular}{|c|c|c|}
\hline Dependent Variable & Definition & \\
\hline \multirow[t]{3}{*}{ Satisfaction } & Do you think immigrants have a positive or negative effect on Missouri? & Percent \\
\hline & Yes & $55 \%$ \\
\hline & No & $45 \%$ \\
\hline Independent Variables & Definition & Mean \\
\hline \multirow[t]{2}{*}{ Age } & Age of the respondent & 56.0 \\
\hline & & Percent \\
\hline Male & Respondent is Male & $48 \%$ \\
\hline Female & Respondent if Female & $52 \%$ \\
\hline White & Respondent is White & $82 \%$ \\
\hline Black & Respondent is Black & $7 \%$ \\
\hline Other & Respondent is Other & $11 \%$ \\
\hline No High School Diploma & Respondent has no High School Diploma & $7 \%$ \\
\hline High School Graduate & Respondent has a High School Degree & $28 \%$ \\
\hline Some College & Respondent has Some College Education & $25 \%$ \\
\hline Collage Graduate & Respondent has a College Graduate & $26 \%$ \\
\hline Post Collage Graduate & Respondent has Post College Degree & $14 \%$ \\
\hline Democrat & Respondent is a Democrat & $27 \%$ \\
\hline Republican & Respondent is a Republican & $23 \%$ \\
\hline Independent & Respondent is an Independent or Other & $50 \%$ \\
\hline Saint Louis & Respondent lives in the Saint Louis Metropolitan Statistical Area & $38 \%$ \\
\hline Kansas City & Respondent lives in the Kansas City Metropolitan Statistical Area & $18 \%$ \\
\hline Other MSA & Respondent lives in Other parts of Missouri & $44 \%$ \\
\hline Immigrant Tie & Respondent has a family Member that is an Immigrant & $44 \%$ \\
\hline Union Tie & Respondent has a family member that is a Member of the Union & $41 \%$ \\
\hline
\end{tabular}

According to MIRAPOS, Immigration was ranked 10th out of 11th public policy themes in terms of importance (See Table 3). The most important public policy theme reported by 


\section{Macrothink}

Missourians was the Economy (mean=4.65) followed by Education (mean=4.58), Social Security and Retirement (mean=4.56), and Terrorism (mean=4.45). The mean ranking for immigration was 4.00 . For the dependent variable, the results showed that $55 \%$ of the respondents had a positive view immigrants compared to $45 \%$ that had a negative view of immigrants.

Table 3. The rank order of importance of public policy issues

\begin{tabular}{|c|c|c|c|c|c|c|}
\hline Variable & Label & Scale & Mean & $\begin{array}{l}\text { Std } \\
\text { Dev }\end{array}$ & Minimum & Maximum \\
\hline Q2A & The Economy & $\begin{array}{c}5=\text { Important } ; 1=\text { Not Very } \\
\text { Important }\end{array}$ & 4.65 & 0.68 & 1 & 5 \\
\hline Q2B & Education & $\begin{array}{c}5=\text { Important; } 1=\text { Not Very } \\
\text { Important }\end{array}$ & 4.58 & 0.75 & 1 & 5 \\
\hline Q2D & $\begin{array}{l}\text { Social Security and } \\
\text { Retirement }\end{array}$ & $\begin{array}{c}5=\text { Important } ; 1=\text { Not Very } \\
\text { Important }\end{array}$ & 4.56 & 0.80 & 1 & 5 \\
\hline Q2I & Terrorism & $\begin{array}{c}5=\text { Important; } 1=\text { Not Very } \\
\text { Important }\end{array}$ & 4.45 & 0.88 & 1 & 5 \\
\hline Q2F & Health Care & $\begin{array}{c}5=\text { Important; } 1=\text { Not Very } \\
\text { Important }\end{array}$ & 4.43 & 0.95 & 1 & 5 \\
\hline Q2K & Government Spending & $\begin{array}{c}5=\text { Important } ; 1=\text { Not Very } \\
\text { Important }\end{array}$ & 4.43 & 0.96 & 1 & 5 \\
\hline Q2E & Moral Values & $\begin{array}{c}5=\text { Important; } 1=\text { Not Very } \\
\text { Important }\end{array}$ & 4.35 & 1.08 & 1 & 5 \\
\hline Q2J & Crime & $\begin{array}{c}5=\text { Important; } 1=\text { Not Very } \\
\text { Important }\end{array}$ & 4.29 & 0.97 & 1 & 5 \\
\hline Q2C & Taxes & $\begin{array}{c}5=\text { Important; } 1=\text { Not Very } \\
\text { Important }\end{array}$ & 4.24 & 0.98 & 1 & 5 \\
\hline Q2H & Immigration & $\begin{array}{c}5=\text { Important; } 1=\text { Not Very } \\
\text { Important }\end{array}$ & 4.00 & 1.16 & 1 & 5 \\
\hline Q2G & Military Presence in Afghan & $\begin{array}{c}5=\text { Important; } 1=\text { Not Very } \\
\text { Important }\end{array}$ & 3.77 & 1.24 & 1 & 5 \\
\hline
\end{tabular}

The logistic regression analysis was centered on four models: (1) base model; (2) familial and union ties model; (3) policy themes model; and (4) the full model. Table 4 presented the results for the four models. In model 1 , three variables were significant: Democrat $(b=.751$, $\mathrm{p}=.001)$, Republican $(\mathrm{b}=-.526, \mathrm{p}=.013)$, and Saint Louis $(\mathrm{b}=.512, \mathrm{p}=.009)$. In model 2, both familial tie variables were significant: immigrant tie $(b=.716, p=.000)$ and union tie $(b=-.454$, $\mathrm{p}=.022)$. In model 3 , all three themes were significant: American values $(b=1.296, p=<.001)$, social justice $(b=.619, p=<.001)$, and Arizona principles $(b=.993, p=<.001)$. In model 4 , there were five significant variables: immigrant tie $(b=.821, \mathrm{p}=.002)$, union tie $(\mathrm{b}=-.580, \mathrm{p}=.028)$, American values $(b=1.251, p=<.001)$, social justice $(b=.686, p=<.001)$, and Arizona Principles $(b=.958, p=<.001)$. Model 4 provided the best overall goodness fit statistics. Model 4 improved the prediction of our dependent by 34.5 percentage points compared to $31.7,14.4$, and 13.2 percentage points, for models 3, 1, 2, respectively (See Table 4). 


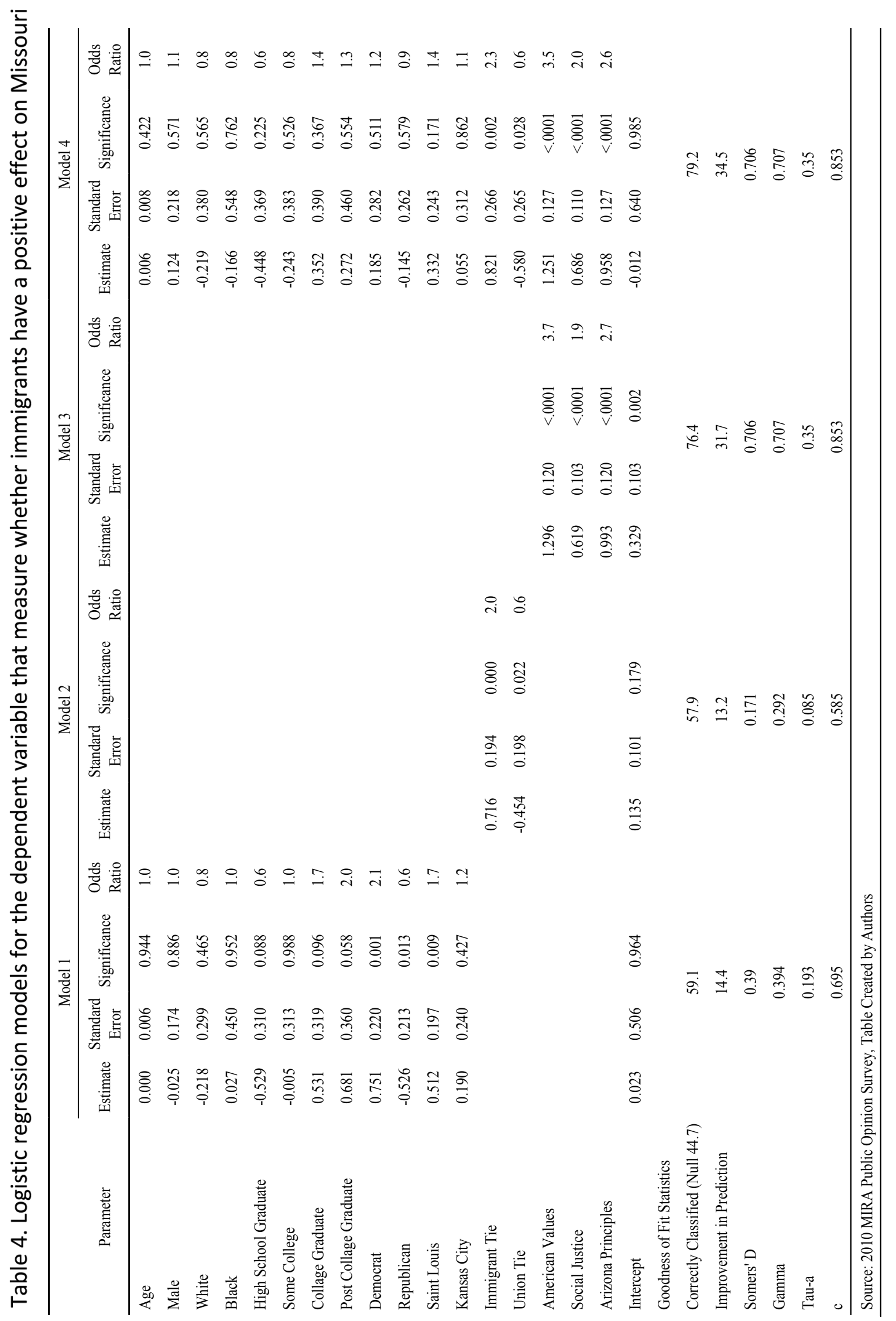




\section{Discussion}

This paper offers valuable insight into the public perceptions of immigrants in a non-gateway immigrant state. The overall results from MIRAPOS were a surprise to the research team. We had prepared ourselves to expect the worse, meaning that the majority of respondents would hold a negative view toward immigrants. However, the results showed that the majority of Missourians held a positive view toward immigrants. The regression results provided mixed results about the remaining research questions that framed this paper.

First, we were surprised to find that the effects of political affiliation were no longer significant once the familial ties and policy theme variables were introduced into the analysis. Rightly or wrongly, there is a public perception that Democrats are more likely to have a positive image of immigrants compared to Republicans in the state of Missouri. Another surprise in the analysis is that the regional effects were not significant in the final model.

Second, we found evidence to suggest that familial ties do matter in regards to the perception of immigrants. Respondents who were an immigrant or had family members who were immigrants were 2.2 times more likely to have a positive image of immigrants. As immigrants continue to migrate in the U.S. and marry U.S. citizens there is a tremendous upside or potential to influence the positive images of an immigrant. The results regarding the union familial tie were interesting. Within the unions, there is generally a dueling perception of the images of immigrants. The general consensus before starting this project was that union members would have a favorable image of immigration. However, the results showed that there was a negative relationship between union familial tie and a positive perception of immigration. Union members or families that had a family member in a union may view immigrants as a threat or unfair competition, in terms of low-wages.

Third, the American value results were the most surprising finding. Those respondents who had positive images of immigrants becoming an American were 3.5 more likely to have a positive image of the impact that immigrants had on the state. This finding underscores the fact that the perception of immigrants and the desire to achieve the American dream will be crucial to any state-wide immigrant rights campaign.

Fourth, the finding regarding the social justice variable was interesting on two levels. The research showed that Missourians have a strong sense of justice when the issues are framed around the idea of accessibility for children of immigrants. For example, only $8 \%$ of respondents strongly agreed with the statement "Denying social services to children of immigrants is all right." Missourians with a strong sense of social justice were 2.0 more times likely to have a positive image of the impact of immigrants in Missouri. The variables that contributed to this social justice factor were consistent with the larger narrative in the U.S. regarding support of "dreamers" regardless of political affiliation, race, or education.

Lastly, the finding regarding whether Missourians think that the state should adopt draconian anti-immigration tactics similar to Arizona was interesting. Missourians that did not support the Arizona principle factor were 2.6 times more likely to view immigrants as a positive asset to the state. 


\section{Limitations of Study}

This study had three major limitations. The first limitation was related to the cross-sectional nature of the data. A longitudinal data set would have provided for a more sophisticated analysis of attitudes towards immigrants. As mentioned in the paper, this cross-sectional study was done in October 2010 weeks before the 2010 national elections and months after the passage of Arizona's anti-immigration bill (SB 1070). We were not able to estimate the impact of these national events on the state discourse of immigration. It is possible that our study underestimates the percent of Missourians that had a positive image of immigration given that the survey was completed when the negative discourse of immigrants was at its zenith.

The second limitation was related to the length of the questionnaire. Because of budget and time constraints, several questions were eliminated from the final questionnaire. When we conducted the analysis in November, we realized that it would have been beneficial to have included some additional questions about the perception of immigrants. For example, a gap analysis that measured the perceived numbers of immigrants relative to the actual number of immigrants living in the state would have been helpful to the analysis.

The third limitation was sample size. Although we achieved our goal to create a sample with a margin of error of $+-3.5 \%$, from an academic perspective we would have preferred a larger sample size. Although we had random sample that was representative of the state, a larger sample would have allowed us to parse the analysis in different analytical sub-sections. This was not possible give the small sample sizes for some group comparisons.

\section{Conclusion}

In this paper, we provide a context to study the attitudes toward immigration using a participatory action framework. The success of this study relied on this framework to ensure that all parties who had an interest in this study were given ample opportunity to contribute to the success of the data collection, analysis, and presentation of findings.

Many people believe that Missouri is a red-state, thus anti-immigrant. It is true that many anti-immigration bills have been sponsored in the state legislature. However, this project demonstrates that such bills are not a true or authentic measure of how Missourians feel about immigration. In this paper, we provide evidence that Missourians had a positive view of immigrants. We found that familial ties to the immigration experience contribute to a positive outlook for immigrants and familial ties to organized labor contribute to a negative outlook for immigrants. We also found that residents that had the perception that immigrants wanted to become American had a favorable perception of immigrants. The paper also provides support for the conclusion that residents who had a strong social justice consciousness regarding children of immigrants had a favorable perception of immigrants. Finally, the evidence presented in this paper showed that Missouri residents who reported a dislike for the Arizona's anti-immigration bill had a favorable image of immigrants. Although immigrants only represent about $4 \%$ of Missouri's population, the unspoken truth is that the majority of Missourians reported that immigrants had a positive impact on the state. 


\section{Acknowledgements}

This research project was supported by the Missouri Immigrant and Refugee Advocates (MIRA) and Service Employees Union International (SEIU) of Missouri. The authors would like to thank MIRA, particularly Board Chair Joan Suarez, their staff (including previous director Jennifer Rafanan), Mountain West Research, Pineda Consulting, and the participants that completed the survey. We also want to thank Joel Jennings who helped write the first draft of this paper.

\section{References}

Binder, N. E., Polinard, J. L., \& Wrinkle, R. D. (1997). Mexican American and Anglo attitudes toward immigration reform: A view from the border. Social Science Quarterly, 78(2), 324-337.

Blumer, H. (1958). Race prejudice as a sense of group position. The Pacific Sociological Review, 1(1), 3-7. http://dx.doi.org/10.2307/1388607

Chandler, C. R., \& Tsai, Y. M. (2001). Social factors influencing immigration attitudes: An analysis of data from the General Social Survey. The Social Science Journal, 38(2), 177-188. http://dx.doi.org/10.1016/S0362-3319(01)00106-9

Citrin, J., Green, D. P., Muste, C., \& Wong, C. (1997). Public opinion toward immigration reform: The role of economic motivations. Journal of Politics, 59, 858-881. http://dx.doi.org/10.2307/2998640

Diamond, J. (1998). African-American attitudes towards United States immigration policy. International Migration Review, 32(2), 451-470. http://dx.doi.org/10.2307/2547191

Dixon, J. C. (2006). The ties that bind and those that don't: Toward reconciling group threat and contact theories of prejudice. Social Forces, 84(4), 2179-2204. http://dx.doi.org/10.1353/sof.2006.0085

Ellis, M. (2006). Unsettling immigrant geographies: US immigration and the politics of scale. Tijdschrift Voor Economische en Sociale Geografie, 97(1), 49-58. http://dx.doi.org/10.1111/j.1467-9663.2006.00495.x

Ellis, M., \& Almgren, G. (2009). Local contexts of immigrant and second-generation integration in the United States. Journal of Ethnic and Migration Studies, 35(7), 1059-1076. http://dx.doi.org/10.1080/13691830903006119

Espenshade, T. J., \& Calhoun, C. A. (1993). An analysis of public opinion toward undocumented immigration. Population Research and Policy Review, 12(3), 189-224. http://dx.doi.org/10.1007/BF01074385

Espenshade, T. J., \& Hempstead, K. (1996). Contemporary American attitudes toward US immigration. International Migration Review, 535-570. http://dx.doi.org/10.2307/2547393

Hainmueller, J., \& Hiscox, M. J. (2007). Educated preferences: Explaining attitudes toward immigration in Europe. International Organization, 61(02), 399-442. 
http://dx.doi.org/10.1017/S0020818307070142

Harwood, E. (1986). American public opinion and US immigration policy. The Annals of the American Academy of Political and Social Science, 201-212. http://dx.doi.org/10.1177/0002716286487001013

Haubert, J., \& Fussell, E. (2006). Explaining Pro-Immigrant Sentiment in the US: Social Class, Cosmopolitanism, and Perceptions of Immigrants. International Migration Review, 40(3), 489-507. http://dx.doi.org/10.1111/j.1747-7379.2006.00033.x

Haus, L. (1995). Openings in the wall: transnational migrants, labor unions, and US immigration policy. International Organization, 49(02), 285-313. http://dx.doi.org/10.1017/S002081830002840X

Higham, J. (1955). Strangers in the land; patterns of American nativism (pp. 1860-1925). New Brunswick, N.J., Rutgers University Press.

Hood III, M. V., \& Morris, I. L. (1997). ¿Amigo o Enemigo?: Context, Attitudes, and Anglo Public Opinion toward Immigration. Social Science Quarterly, 78(2), 309-323.

Lopez, L., \& Pantoja, A. D. (2004). Beyond Black and White: General Support for Race-Conscious Policies among African Americans, Latinos, Asian Americans and Whites. Political Research Quarterly, 637-642. http://dx.doi.org/10.1177/106591290405700411

Martin, S. (2003). The politics of US immigration reform. The Political Quarterly, 74(s1), 132-149. http://dx.doi.org/10.1111/j.1467-923X.2003.00586.x

NCLS. (2013). State Laws Related to Immigration and Immigrants. Retrieved September 27, 2013, from http://www.ncsl.org/research/immigration/state-laws-related-to-immigration-andimmigrants.aspx

Pantoja, A. (2006). Against the tide? Core American values and attitudes toward US immigration policy in the mid-1990s. Journal of Ethnic and Migration Studies, 32(3), 515-531. http://dx.doi.org/10.1080/13691830600555111

Portes, A., \& Rumbaut, R. G. (2006). Immigrant America: A Portrait. Berkeley, CA, University of California Press.

Quillian, L. (1995). Prejudice as a response to perceived group threat: Population composition and anti-immigrant and racial prejudice in Europe. American Sociological Review, 586-611. http://dx.doi.org/10.2307/2096296

Scheve, K. F., \& Slaughter, M. J. (2001). Labor market competition and individual preferences over immigration policy. Review of Economics and Statistics, 83(1), 133-145. http://dx.doi.org/10.1162/003465301750160108

Simon, R. J., \& Lynch, J. P. (1999). A comparative assessment of public opinion toward immigrants and immigration policies. International Migration Review, 455-467. http://dx.doi.org/10.2307/2547704 


\section{Macrothink}

International Journal of Social Science Research

ISSN 2327-5510 2014, Vol. 2, No. 2

Suárez-Orozco, C., \& Suárez-Orozco, M. M. (2001). Children of Immigration. Cambridge, MA, Harvard University Press.

Walker, K. E., \& Leitner, H. (2011). The variegated landscape of local immigration policies in the United States. Urban Geography, 32(2), 156-178. http://dx.doi.org/10.2747/0272-3638.32.2.156

Wilkes, R., Guppy, N., \& Farris, L. (2008). "No Thanks, We're Full”: Individual Characteristics, National Context, and Changing Attitudes Toward Immigration. International Migration Review, 42(2), 302-329. http://dx.doi.org/10.1111/j.1747-7379.2008. 00126.x

\section{Copyright Disclaimer}

Copyright reserved by the author(s).

This article is an open-access article distributed under the terms and conditions of the Creative Commons Attribution license (http://creativecommons.org/licenses/by/3.0/). 